\title{
The Medical ORIgins OF HeREdity
}

\section{CARLOS LóPEZ-BELTRÁN}

Such as the temperature of the father is, such is the son's, and look at what disease the father had when he beget him, his son will have after him... as is as well inheritor of his infirmities as of his land. (Jean Fernel, 1554, quoted from Burton, 1621)

Either no causation governs this matter (of hereditary descent) or else the most minute constitutional peculiarities of children are caused by similar elements in their parents. Then let parents learn and remember that their prospective children will be the very images of themselves, reflected in all their shades of feeling and phases of character... inheriting similar tastes, swayed in similar passions, governed by kindred sentiments, debased by the same vices, ennobled by like virtues, adorned by kindred charms and graces, and endowed with similar moral powers and intellectual capabilities. (Fowler, 1848)

Biological heredity began by being human heredity. As the Jean Fernel’s (1497-1558) famous assertion reveals, the first scene for this notion was a metaphorical one built upon the analogy between transmission of wealth and other legal goods and the common observation of physical similarity between parents and offspring (“Like begets like”). In this 
case a not very welcome kind of similarity. Human heredity begins thus with the observation that genealogical relationships between persons imply more than social bonds: there are also physical rapports manifested by looks and by health. The inference that something could be passed on from parents to offspring in the act of generation that accounts for the perceived similarities is natural enough for us; not so for those living under different physiological and theological frames, in which similarities could be accounted for in different ways or dismissed as accidental or irrelevant ${ }^{1}$. Similarly, the metaphor that was found suitable for such transmission (as land, craft, wealth and title were inherited, so could body and mind -or some of their features- be inherited too) was far from natural when it first was deployed. This metaphor of inheritance was one that took a long time to become acclimatized in modern biological thought. It took several paths that coincided towards the third decade of the $19^{\text {th }}$ century when our modern concept of heredity finally acquired its basic structure.

The idea of a human biological heredity was negotiated between the early modern period and the mid-nineteenth century, and its status shifted in consequence from a simple suggestive metaphor to a fully-fledged natural law. From the superficial reference of transmission of general features, such as land or temperament, to the deep-rooted one of peculiar powers and dispositions, linked in an essentialist way to family and race. The extremes of this long durée negotiation are neatly captured by the quotes by Fernel and the American phrenologist Orson Squire Fowler (1809-1887) above ${ }^{2}$. The quotations also define the main territory in which such negotiations took place; that of the medical question about the hereditary transmission of disease. The epochal shift from a metaphorical use to a

\footnotetext{
${ }^{1}$ For a discussion of such theological and physiological frames and their relation to hereditary transmission see López-Beltrán (2002) and Silvia de Renzi in this volume. See also the relevant chapters in Roger (1973)

2 This long term developments are described from another perspective by David Sabean in this volume.
} 
causal, explanatory notion, as I have also noted elsewhere, is reflected by a linguistic shift, i.e. the adoption of the noun heredity in several European languages after the second decade of the $19^{\text {th }}$ century. The ubiquitous noun we use today (heredity) only acquired its modern conceptual frame as a structured, causal, mechanistic presence in the biological realm when what I have called the reification of the metaphor was achieved ${ }^{3}$. My aim in this chapter is to highlight how an important set of developments helped materialize such reification took place within the European medical preoccupations with hereditary transmission of disease. The adoption of the phrase haeraeditarii morbi, from Arab medical translations, and the increase in attention in such possibility after around 1600, set off a trajectory I aim to describe here, within which the theoretical (physiological) sorting out of is it that something as a proclivity, or a disposition to acquiring a given ailment, could in fact be passed on from ancestors to descendants.

Since antiquity till the 18th century, the adjective "hereditary” was loosely employed when a given trait was found to characterize a family or another genealogical group. I have proposed we should maintain the adjectival terminology, using the formula "the hereditary" to refer to the set of phenomena naturalists and physicians could associate with temperamental similarity: resemblance to both the father and the mother, general temperamental dispositions, peculiar gaits, physical marks (moles, large heads, etc.) ${ }^{4}$. The reference to the hereditary nature of a trait occurred however with much more frequency and consistency when anomalies, moral or physical were the subject. "Hereditary gout" or “hereditary depravities” were more common formulas than their positive counterparts. In

\footnotetext{
${ }^{3}$ López-Beltrán (1994)

${ }^{4}$ The issue of resemblance, particularly to the father, as being part of the hereditary in the early modern period, has important legal consequences that are been discussed in Sivia de Renzi's excellent paper in this volume.
} 
fact, as Maaike van der Lugt and myself have discussed, it is quite likely that the use of the hereditary metaphor was filtrated into European languages from translations of Arabic medical treatises (mainly Avicenna) when translating their notion of "hereditary disease"5 I shall maintain in this chapter that some of the most important steps that moved the notion of hereditary transmission of physical features from the early modern accidental perspective to the $19^{\text {th }}$ century essentialist approach are to be found among European medical men. The early modern medical notion of haereditarii morbi (hereditary disease) was a main hinge over which the metaphorical flow of structured meaning passed from the legal to the biological. The long durée efforts of physiological clarification of such notion became the motive to keep the transmission metaphor alive for many decades, until it became developed into the powerful explanatory tool of $19^{\text {th }}$ century naturalists, physiologists and, on another path, of psychiatrists, social reformers and novelists of $\operatorname{doom}^{6}$.

To show this I will focus on a series of essays written in response to two prize competetions issued by the Parisian Société Royale de Médécine in 1788 and 1790, a period coinciding with the start of the revolutionary period in France and the redefinition of the role of the medical profession entailed by the revolution. After describing the background this competition had in seventeenth and eighteenth century medical theories of inheritance, I will try to show that an understanding of the much more structured, and theoretically sophisticated, notion of hereditary transmission we find in the answers to the said prize competitions, provides a better historical understanding of the apparently sudden appearance of a biological concept of heredity in the first decades of the $19^{\text {th }}$ century. The

\footnotetext{
${ }^{5}$ See van der Lugt (forthcoming) and López-Beltrán (forthcoming)

${ }^{6}$ See Olby (1994) , Borie (1981), Morgentaler (1999), Malinas (1985)
} 
conceptual space on which naturalists framed their preoccupations concerning hereditary transmission of physical features, specially after the first three decades of the $19^{\text {th }}$ century, was a space carved out by medical men in the first place. Heredity, I repeat, started out as human heredity. As human pathological heredity.

\section{EARLY MODERN PHYSIOLOGIES OF HEREDITARY TRANSMISSION}

The characterization of a given disease as hereditary poses and inmediate puzzle to the physician; the metaphor implies the existence of a fact of transmission. A given failure in the health of a person is being seen as attributable to a particular presence in his body of a trait (a mark, a flaw) that was transmitted by at least one of his parents to him through physiological routes linked directly to the act of generation. This inference is not necessarily supported by every physiological frame, but the metaphor points strongly for it. The existence of family patterns in the ocurrence of certain diseases, which has been known since antiquity, is only an indication of the possibility that actual bequetal of diseases happen. Under a hippocratic-galenic (humoral) view of disease this transmission could be portayed in different fashions. Most hereditary diseases were linked to chronic, basic, temperamental ailments rooted in in fundamental imbalances acquired by the individual during his “first formation”. At that moment (under the prevailing dual seminal view of generation) the seminal contributions of both parents became fused and stabilized in the new individual's temperament. Of course many circumstancial influences (climatic, 
emotional, imagination, etc. ${ }^{7}$ ) could alter the outcome -the child's temperament- and the high variability in the physical (and moral) attributes of children from the same parent's could testify for that,. Nevertheless the tendency (like engendering like) of reproducing the parents temperamental characteristics was a given regularity for physicians. That included the re-production of some of the diseases one's parent's had had, at the same period of life they had been afflicted by them. This phenomena gave motive to Michel de Montaigne (1533-1592), when struck by the same disease his father had at the same age to pose the question of transmission

What monster is it that this teare or drop of seed whereof we are ingendred brings with it, and in it the impressions, not only of the corporal forme, but even of the very thoughts and inclinations of our fathers? Where doth this droppe of water contain or lodge this infinite number of formes? And how bear they these resemblances of so rash and unruly a progresse, that the childe's childe shall be answerable to his grandfather, and the nephew to his uncle? ${ }^{8}$

This basic question produces several physiological and causal puzzles. If physical and moral resemblance between parents and offspring is a normal outcome of process of reproduction, a side effect, so to speak, is communication of hereditary disease effected by the same route and causes? Are such diseases the product of specific morbid humoral

\footnotetext{
${ }^{7}$ For alternative explanations of the hereditary in the 18th century see López-Beltrán (2002). For the attribution of influence to the mother's imagination see Huet (1993), and for the legal aspects of such attribution see Silvia de Renzi in this volume.

${ }^{8}$ Montaigne (1582), livre II, ch. xxxvii; English translation quoted from Montaigne (1999).
} 
materials that can be erradicated from the family line, or are they just the product of holistic, general temperamental weakness that befalls in some of the children of a constitutionally prone family?

A hippocratic-galenic explanation of hereditary transmission of disease, particularly exploited by Paracelsians ${ }^{9}$, was to attribute the familial pattern of some diseases to the communication of of peculiar, noxious, poisonous physical elements (taints, bad humours, salts) that had found their way through the "pangenetic" route, and could jump, via the semen, from generation to generation, participating of the original matter from which the new organism would be formed each time. Such noxious materials could have specific evil effects, and thus be responsible for the outbreak of a particular kind of disease, or they could possess a general capacity to damage any part of the system they happened to land upon, triggering different diseases according to the moment and place they become active. As can be seen in Montaigne’s puzzlement, a particularly mysterious phenomena, in these considerations was the latency shown by the causal factors involved. Both resemblances and hereditary diseases could remain hidden for many years during an individual's life, and show themselves with uncanny timing at exactly the same age every time around. They could also skip one or several generations only to reappear in distant relatives.

There is a problem in the physiological equating of normal resemblances and pathological ones. However, the allegation in the latter case that what is hereditarily transmitted is not the disease itself but a constitutional disposition to it, made clearly by physicians since the 17th century, eventually promoted the unification of pathological and non-pathological hereditary transmission. All these considerations made the sorting out of hereditary physiological influences particularly difficult, specially in a critical period when

\footnotetext{
${ }^{9}$ Like the Irish physician de Meara (1619)
} 
physicians were trying to erradicate any appeal to magical or mysterious influences from their scientific outlook. In the context of the crisis that hippocratic-galenic physiology was suffering in the $17^{\text {th }}$ and $18^{\text {th }}$ century in European schools, the questions around hereditary transmission of disease acquired increasing relevance.

At some point in the $18^{\text {th }}$ century physicians embarked on a conceptual quest to make sense of the idea of an hereditary disease, and restrict its boundaries as clearly as possible. European physicians felt the need, long before other naturalists, to focus on genealogical patterns of trait transmission. A main objective for them was to have criteria to distinguish those diseases that could properly be called hereditary from those which, sometimes adopting similar patterns of occurrence, were not transmitted in the act of generation and had to be set apart. As a consequence, observation of the characteristics, and development of candidate diseases, became increasingly crucial to the discussion. The timing and duration of their attacks were seen as important telling factors concerning the origin and ultimate cause of the disease. A disease acquired at the moment of conception by parental influence (the main criteria for its hereditariness for most authors) ${ }^{10}$ would typically be a constitutional, chronic disease, and manifest itself at the same age, more or less, in the offspring as it had on the affected parent. The more analytic authors tried to discuss and eliminate the other possible, non-hereditary, causal influences.

In the process of clarifying what the adjective hereditary meant to them, the medical men began to give structure and causal meaning to what had started out as a metaphorical, purely descriptive term. As I have detailed elsewhere, this process seems to have gathered momentum after 1600, when medical physiologists were trying to adjust their traditional

\footnotetext{
${ }^{10}$ For a discussion of the importance of the moment of conception for hereditary discussions see LópezBeltrán (2002).
} 
hippocratic-galenic views of disease to the less dogmatic and more empirically oriented scientific environment of the post-Renaissance ${ }^{11}$. As a base for the discussions on hereditary disease, the collection of relevant ancient and modern evidence, registered in the form of more or less trustworthy cases in the literature, was increased enormously during these two centuries (1600-1800), and it eventually became, in itself a very powerful tool against the sceptics, who from different quarters tended to dismiss the claims of specific hereditary trasnmission of physical ailments as delusions or physiological impossibilities. During the18th century several important medical authors were still highly sceptical about the real possibility of there being any causal communication (through the seminal fluids or other) between the temperament or constitution of parents and that of the children. In his youth, in 1748, the French military surgeon and later lifetime secretary to the Académie royale de Chirurgie Antoine Louis (1723-1792) articulated very lucidly these doubts in his influential Dissertation... sur la question ...comment se fait la transmission des maladies héréditaires?. ${ }^{12}$

In consequence, physicians interested in hereditary transmission embarked on the production of theoretical distinctions based on the accumulated evidence, distinctions that began to give the subject a more sophisticated profile. Their need to provide physiologically possible causal routes to disease made them realize that a simple external pattern, familial, group, regional, or other, was not enough for claiming an hereditary cause for a disease. In other words, their need to establish clear criteria for recognizing the hereditary diseases (which were mostly identified with constitutional ones) from those “acquired" after conception (both congenital, and post-natal), forced them to focus on

\footnotetext{
${ }^{11}$ See López-Beltrán (forthcoming)

${ }^{12}$ For close analysis of Louis (1749) see López-Beltrán (1995), 310-320, and (2002).
} 
peculiarities of original source, timing of appearance and of recurrences. By the end of the 18th century there were circulating among medical men, mainly but not exclusively in France, a series of quite sophisticated distinctions, and definitions of what is meant for a disease, and a physical feature in general, to be hereditary.

The roots of the criteria developed by 18th century physicians in their attempts to define the hereditary can be traced back to the writings of Hippocrates and Aristotle, but became increasingly stringent and logical at the exclusion of the non-hereditary during this time. The more subtle and careful thinkers, amongst medics, wanted to claim as properly hereditary only those constitutional characters and diseases that, coming from any one of the parents, established themselves as part of the organic constitution before the first solidifications of the seminal humors in the womb gave rise to the new individual in all its complexity. For other authors, other sources of parental humoral influences, beside the seminal ones, had to be considered within the realm of the hereditary: the maternal ones via the placenta, and for the more inclusive or least discriminatory of them, also the influence of lactation on the newborn's constitution. Non-humoral sources of influence were also discussed, like the emotions and imagination of the mother ${ }^{13}$.

\section{LES MALADIES HÉRÉDITAIRES AT THE THRESHOLD OF THE REVOLUTION}

In the years 1788 and 1790, in a momentous period in French history, the Parisian Société Royale de Médécine called for two successive essay competitions in which the issue raised was the reality, the evidence and the theoretical support for a belief in the existence

\footnotetext{
${ }^{13}$ See Silvia de Renzi's contribution to this collection.
} 
of hereditary diseases. The tone in which the questions were set made it clear that the Society wanted some real theoretical progress and did not want the competitors to rely on unsupported ancient tales and assumptions around the phenomena of hereditary transmission of disease. The questions set for answer by the Society on the public session of February 27, 1787, with a prize of “600 livres” were: "Determine 1) if there are truly hereditary diseases; 2) if it is in the power of medicine to prevent their development or to heal them after they break out." ${ }^{\circledR 14}$ The permanent secretary of the Société Royale, Felix Vicq D’Azyr (1748-1794) himself took a keen interest in the organization and the outcome of these competitions. Judging for the importance that the Sociéte Royale gave to the essay prizes, it seems very likely that the having a sound view of hereditary transmission of disease had become an issue that surpassed its mere theoretical importance. French physicians associated with the Philosophes, like Pierre Jean George Cabanis (1757-1808), Phillipe Pinel (1745-1826) and D’Azyr himself, were struggling to transform the profession into a more socially relevant one ${ }^{15}$. Hereditary transmission of disease, which up to that moment had been a worry only in relation to family medicine (in some cases associated to royal families ${ }^{16}$ ), was being considered as a public hygiene problem. The sceptic challenge that the surgeon Antoine Louis had raised in a similar context of a prize competition issued by the academy of Dijon in 1748 , was also a main motivation for the Société Royale. Having posed with such clarity the challenges facing any real physiological attribution of an hereditary transmission of disease, and having Louis himself acquired such a notorious position within the ranks of the rival Société de Chirurgie, physicians of the Société Royale

\footnotetext{
${ }^{14}$ See Histoire et Memoires de la Société Royale de Médecine, vol. IX, 1786-87, p.17.

${ }^{15}$ See Williams (1994) For D’Azyr's views on the social role of medicine see Mandressi (2004)

${ }^{16}$ Luis Mercado's treatise (1594) is a specific example of that.
} 
had to produce a plausible rationale, preferably under an acceptable solidist account, which both a sugeon like Louis, and a anatomist like Vicq D’Azyr would prefer.

The focus that the Société Royale forced upon hereditary transmission of disease in this critical moment produced, I believe, a notorious theoretical enlightenment of the difficulties facing the notion of hereditary transmission in general. The collection of essays sent to the competition (most of then unpublished manuscripts) remain a valuable source for elucidating hereditary hinking of the epriod. The high standards set by the jury payed off. Finding that the participants hadn't produced acceptable critical analysis of the question posed, the jury to the first contest (D’Azyr among them) decided not to grant the prize, but to call for a rerun with the same questions but raising the prize money to 800 livres. ${ }^{17}$ In their summing up the judges of the first contets detailed their discontent: Most of the participants made the supposition rather than proving the existence of hereditary diseases; thay have not defined enough their nature. We need to know if some morbific vices are really and individually transmitted from parents to children, or if the diseases that are called hereditary, are not rather a consequence of the conformation of the organs, which in parents and children must, due to their structure, subject to the same affections. It is mainly on the existence and nature of these diseases that their research must directed towards. ${ }^{18}$

\footnotetext{
${ }^{17}$ Minutes d'examen de memoires sur maladies héréditaires, 181-23-1,5, Archives de L'Ancienne Société Royale de Médecine, in Library of the National Academy of Medicine, Paris. See appendix 1 in LópezBeltrán (1992).

${ }^{18}$ Société Royale de Médecine (1786-1788), p.18.
} 
This wording was motivated by the weakness found in many of the essays that adopted a humoralist view. As I mentioned, earlier scepticism about the reality of hereditary transmission of disease voiced by Antoine Louis’ and other influencial physician's had particularly exploited such weaknesses. They had argued that diseases that seem hereditary are only due to common defect of conformation of the solid parts, and there is no clear way in which the individual conformation of the parents body can have a regular, direct causal effect on the conformation of the embryo. Transmission of disease through humoral influences, even if sometimes derived from a parent, cannot be said to have any special route or character that would justify their separation into a different category; then there is thus no realistic sense in in which to interpret physiologically the old analogy of inheritance in relation to disease. ${ }^{19}$

Another set of judges confronted in 1790 a new and more carefully argued set of pieces. According to them, at least four dissertations of very high quality. These were those dissertations written by Pierre-Joseph Amoreux (1741-1824), Alexis Pujol (1739-1804), Jean-François Pagès (***_***) and Joseph-Claude Rougemont (1756-1818). ${ }^{20}$ Although not agreeing in all aspects, these works gave strong and authoritative accounts of the reasons why a physician of the late 18th century could and should defend the principle of hereditary transmission of disease (or as some of them insisted, of a disposition to it) regardless of what some sceptics argued. Yet, the Royal Society was still not fully satisfied. Even after the clarifications of the mentioned essyas, the question — the judges stated— was not yet solved. There remained a need of "nouveaux éclaircissemens" that medical men would need to apply their zeal to. "Isolated observations,” they added, “considered

\footnotetext{
${ }^{19}$ For a more detailed account see López-Beltrán (1995).

${ }^{20}$ Other dissertations could be added to this list. For instance those of Ladèvere (1790) and Girard (1790) were excellent in some aspects but were less well rounded.
} 
separetly cannot have but a very limited degree of usefulness. It will not be but on their gathering and their comparison that we will be able to give them their value.” ${ }^{21}$ This invitation to surpass the casuistic method that had plagued the subject for too long and gather the evidence in a more cummulative fashion, was a clear recognition that the consensus amongst wider sectors of the medical community was changing, away from their old, case-based and bookish inductive strategy, towards a more modern approach. In several competition essays, authors had acknowledged that Antoine Louis had a point when he questioned the use of tales and anecdotes to justify belief in hereditary disease, and was right when he wrote that "the principles which form the true theory of medicine can only be acquired by fastidious researches and long and difficult labor.”22

Though not completely satisfied, the Société Royale commisioners decided to grant the prize to the caribbean born physician Joseph-Claude Rougemont's, whose contribution according to the judges, treated the question under all its aspects, and made an "exact and severe analysis of all the writings and all the facts related to the problem posed”. For instance, he carefully distinguished hereditary diseases from those that the child can contract within the mother's womb or during birth. Some shortcomings in method, they added, were balanced by the clarity he brought to the whole subject. ${ }^{23}$ Unfortunately the manuscript of this essay is missing from the archive, and Rougemont's text was never published in French. As he was Professor of Anatomy and Surgery at Bonn University at

\footnotetext{
${ }^{21}$ “Dans ce genre les observations isolées considerées séparément, ne peuvent avoir qu’un degré d’utilité trèsborné. Ce ne sera qu'en les réunissant \& en les comparant, qu'on pourra leur donner de la valeur”. Histoire et Memoires de la Société Royale de Médécine, vol. IX, 1787-88, pp.x-xi, Paris.

${ }^{22}$ Louis (1748) p.4.

${ }^{23}$ Société Royale de Médecine (1786-1788), vol.9, pp. x-xi.
} 
the time, his work on hereditary disease was published in Franckfurt (1794), in a German translation, and was a classic on the subject in early 19th century Germany. ${ }^{24}$ An “accesit” prize was given to Amoreux, the son of a known physician who taught most of his life at Montpellier. While his great historical erudition was highlighted, he failed, according to the judges, on the "prophilactique \& curatif” aspects. Both Pujol and Pagès received honorary mentions. Pujol, who lived and worked at Castres, and won several prizes with his essays at Royal Society Competitions, had extended this first version considerably for the 1790 re-run. Though considered “trés Bon” and “erudite” by the judges, he refused to eliminate the theological bits, which according to him, were the reason why he did not win. Pagès’s original manuscript is also missing from the archives, but it was published in the Encyclopedie Méthodique in 1798. Thus only a few of the dissertations written for the competitions found their way to publication. Perhaps the most widely read was Pagès’s piece. Together with Rougemont’s winning essay, this essay was among the more modern and better argued, and it was the solidist position that received a backing in both. Amnoreux and Pujol, in contrast to that, had tried to integrate humoralist and solidist positions in their contributions.

Several of the contenders of the second round began their pieces revealing certain outrage at the 1788 judge’s decision to demand further proof of the existence of hereditary transmission of disease, claiming that the overwhelming number of indubitable cases gathered in the literature —and witnessed during their practice— - was enough to take any reasonable person close to certainty. Puzzled by this first essay’s failure to convince the judges, Amoreux, for example, had reworked it considerably for the 1790 contest, adding

\footnotetext{
${ }^{24}$ Steinau (1836); for bio-bibliographical details on Rougemont see Dezeimeris et. al. (1828-1839), vol. 4, pp.24-25. In the same work information can also be found on Alexis Pujol (vol.3, pp.764-65), and PierreJoseph Amoreux (vol.1,p.111).
} 
many "evidences from authority” as well as an increased number of facts collected from all sorts of sources. In this point, Amoreux, Ladàvere, Pujol, among others, did try to justify their inductive procedures, and felt somehow betrayed by the Société Royale’s siding with Louis in this issue. They believed that carefully selected cases, accompanied by sound physiological and pathological knowledge, did provide a good base for making general statements about hereditary transmission. The adequate selection of old authorities, and specially the experience that many years of practice with sometimes different members of the same family gave to the best observers amongst medical men, clearly provided them with a sound basis for belief. On the other hand, sheer accumulation of cases never would compensate for the combination of a well trained eye with a well read mind that good, old style physicians had.

As for theoretical progress, some important analytical features were already in place.When reading the mansuscripts of the1788 entries, one finds in several authors an insistence about the need of a clearcut distinction between "congenital” and "connate” (conne) causation in order to sort out the hereditary from the non hereditary ${ }^{25}$. This feature was present not only in the winner (as mentioned by the judges) but in several of the second series of essays. The judges praised this feature as it was the main source for having important and clear-cut phenomenological criteria to distinguish the hereditary from other influences. The most important of these criteria was homochrony the ocurrence of a disease effect at the same period in the life cycle. Other criteria included the specificity of the disease and its incurability.

\footnotetext{
25 This distinction was made with clarity already by early modern authors like Mercado (1594) and de Meara (1619). Surprisingly, John Hunter and his followers claimed originality when they tried to argue for it, as in Adams (1814).
} 
The distinction between “congenital” and "connate” causation was made by many authors in slightly different ways. The meaning of this vocabulary is sometimes confusing, and as Pujol pointed out even the Societies’ commissaires seem not to have had the distinction clear themselves ${ }^{26}$. Tipically the connate diseases are those acquired after the first formation of the foetus, by contact in the mother's womb with her humors (through her blood). Some authors include among these those diseases and defects acquired by mechanical influences during pregnancy (blows, etc.), and others believe that mother’s spirit, imagination or states of mind can also exert some kind of influence and produce connate peculiarities. Congenital presences would in constrast be those that were integrated to the individuals constitution at the moment of his first formation via the parent's seminal contributions. But was there a real, important difference picked out by the distinction, or was it jus a nicety with little subtance. The main reason for confusion was of course the coexistence of different physiological explanations of disease in general, and of its transmission in particular. The most salient theoretical divide being that between solidist and humoralist physiologies. The issue of of what sort of material influences to include in the congenital and what to leave outside of it (in the connate) strongly depended on the previous theoretical commitment to one or the other, or to some eclectic combination.

Under a solidist viewpoint the congenital influence was the only kind of truly hereditary character. Humoralists were more divided around this matter, some wanting also to restrict the hereditary to influences at the first formation, while others saw no reason for this restriction, considering any humoral cause communicated by any of the parents before the constitution of the infant becomes completely fixed (i.e before the end of the first year) as worthy of being called hereditary. Under humoralism many authors did not see any

\footnotetext{
${ }^{26}$ Pujol (1802) p. 231
} 
reason why not to include in the hereditary such influences as that exerted over child's constitution by the mother or the nurse's milk. Ayway, the distinction between congenital and connate was difficult to carve out theoretically. The best participants in the 1790 contest can be said to have brought to it a renewed clarity. The solidists seemed to have had the upper hand in this as they could argue for a simpler notion of hereditary transmission that reduced it to the sole seminal influence stemming from the parents and the state of the body once it was completely formed.

Notwithstanding, humoral causes for hereditary diseases were defended by several of the contenders. Pujol, for instance, was specially annoyed that the Société Royale rejected his first essay and attributed it to a dogmatic upholding of solidism . He decided to write for the second (1790) contest a whole new chapter trying to challenge this accusation by arguing in favor of humoralism. Pujol started by contending that "the transmission of virulent and humoral vices by the route of heritage will nerver be proven completely with speculative reasons.”27 Due to the close interdependence between humors and solids, Pujol claimed, it is never easy to isolate the original bearer of a morbific cause. Ill humors affect solid parts as much as diseased solid parts alter the fluid parts’ normal composition. ${ }^{28}$ To restrict the hereditary to solid-solid transmission is, according to him, to blind oneself to empirical evidence, both physiological and pathological. Different tainted humors can act over solid structures at different times, it is sufficient to show that some of them have acted on the conformation of the germ before or at the moment of its fecundation, or that it was incorporated to its bodily fluids at that moment by forming part of the semen, to call its

\footnotetext{
27“"la transmission des vices humoraux et virulens par voie d’héritage ne sera jamais prouvée complétement par des raisons speculatives”. Pujol (1802) p.228.

${ }^{28}$ “'Un virus transmisse une organisation vicieuse derangeront bientot l'harmonie qui doit regner entre les parties solides et les fluides; de la des maladies organiques et des maladies humorales” Amoreux (1790) p.11.
} 
effect hereditary. Many observations point in that direction, he continues. The fact that some of these "ferments (levains)" can also be communicated non hereditarily is no reason to deny this. Amoreux adds in his contribution that strict solidism is untenable because many real hereditary diseases cannot be unambiguously classified as either humoral or solid.

The capacity that humoral vices have to produce many different kinds of effect on different organs at different times (what can be called their "proteism”), that was given by solidist opponents (like Louis and Pagès) as a main reason for discarding them as bearers of real hereditary influences, was seen by Pujol and Amoreux as a further reason for keeping them within the field. Following the "transformations" of humoral hereditary diseases from generation to generation within a family would eventually lead to a reduction of hereditary influences to a small set that could account for the observed diversity. ${ }^{29}$ Hereditary causes then are not only reduced in number but they gain in "extension”. Dispositions to different diseases need not have each a particular humoral cause, but perhaps only a particular effect over an organ or tissue. All hereditary diseases might still depend on constitutional flaws, but they would need a tainted humor as a vehicle for unespecific transmission. ${ }^{30}$

The curability of some hereditary diseases was also at the root of the defense of humoral causes for them. It was widely believed amongst 18th century physicians that humors could more easily be affected by medical treatments than solids. The former could be affected by both nutritional, chemical, and some therapeutical means (like blood-letting) whereas most of the latter were incurable, and only the symptoms could be ameliorated.

\footnotetext{
${ }^{29}$ Contrary to Pagès, both these authors accepted as hereditary a whole range of very different diseases, most of which adopted familial patterns. The idea to follow this transformations in time was taken from some ancient authors, and was retaken later on by several 19th century hereditarians and advocates of degeneration. See for this, Dowbiggin (1991), Waller (2001).

${ }^{30}$ Portal (1808) took this position to an extreme when he wanted all hereditary diseases to be caused by one proteic vice, the scrofular.
} 
Contrary to the claims of both Pujol and Amoreux, however, their dual causal approach to the hereditary left too much room for all kinds of diseases to be considered, one way or another, as hereditary. This proliferative and unbounded character (as both author's rich classifications show) ${ }^{31}$ was precisely what some judges were against, and what was at the root of the Société Royale’s quest for “Maladies vraiement héréditaires”. That is why -I believe- they were not favoured in the competitions.

Disagreements between humoralists and solidists went beyond what kind of physiological interactions the different constituents of the body might undergo, to include which of them were capable of actual hereditary transmission. However, the obscurities surrounding generation, and the impossibility to trace the details of physiological interactions, forced the decision of how to define the hereditary towards external evidence, which could not in the end tip the balance one way or the other, but only draw some limits or boundaries. As Silvia de Renzi argues in this volume, the implications of the reality of some physiological routes of transmission of resemblances within families went beyond medical issues. Paternal and maternal material influences on the childs body could become a legal matter. What was possible and what not became then something socially and politically charged. Under humoralism all resemblances (moral, physical, pathological) within a family (or wider genealogical groups) could be attributed to the similarities in the proportions of the different humors, affected both by internal and external presences ${ }^{32}$. With the rise in the 17th century of mechanistic solidism, family (and group) resemblance became linked with the explanation of the origin of solid parts during the first formation, and the posterior

\footnotetext{
${ }^{31}$ Amoreux (1790) considers a list of 31 different kinds of diseases, and to most of them he grants some "heritability”. Pujol mentions at some point the existence of an “échelle d'hérédité” of diseases, in which all known ailments can be accomodated according to their feasibility of being inherited.

32 See López-Beltrán (2002)
} 
malleability under the action of humors was held then to be an open matter. Strict solidists believed that once completed the formation of solid parts external influences (humoral or other) were of secondary importance.

Alternative generation theories had different bearing on this issues. Pre-existence could provide a base for the radical questioning of the reality of any causal link between parents' and offspring's organizations, i.e. of their resemblances. Constitution (solid organization) is something that comes with the pre-existent germ, and any predisposition to disease (or diathesis) is either already there, or is acquired, but not inherited; unless you open your criteria and include humoral causes into the hereditary, in which case the problem exists of separating those causes from other, external humoral influences. Thi position was adopted in Rey (1748), and also — with variants — by many of the 1788 and 1790 competitors that were not prepared to abandon humoral hereditary influences. The pre-existentialists among them (especially Bésuchet) used Charles Bonnet’s (1720-1793) ideas about the influence of seminal humors in the transformation of the germ during its development. A reason being that so some of the traditionally hereditary diseases seemed to be of a humoral nature (like scrofula). On the other hand (and under the assumption that lodged in different organs, one morbid humor would produce different diseases) the inclusion of humoral causes among the hereditary provided an economy of causes, given that the persistence in one family of only one kind of morbid humor could account for different affections in different individuals and generations. Very many 18th-century medics seem to have believed this. The strictest solidist in the 1790 competition was Pagès. Where others were prepared to accept that certain hereditary diseases had as their main cause a morbific humor ("levain”, “virus”), Pagès was inflexible in his refusal to allow that. He related his solidism also to the disputes over generation. Although he denied that generation theories should 
have a primal position in the discussion about hereditary disease, ${ }^{33}$ he argued that dual seminal views (like Hippocrates’ or Maupertuis') made it easier to account for hereditary transmission of constitutional traits to offspring, both from father and mother, and from ancestors; and would also help draw a line between real hereditary influences (internal: incorporated into solids at first formation) and secondary (humoral, external) ones. The obscurantist and abusive practice of many physicians in applying the adjective to any —and every — disease could be checked, Pagès believed, with clearer external criteria, derived from a clear definition. The principal criteria had to be the time of appearance of the disease. An essetial character — he wrote — of hereditary dispositions is that they develop in the offspring in the same period, at the same age, they appeared in parents. ${ }^{34}$ In his view, only a small set of specifically transmitted (through generation, in semen) constitutional predispositions to certain diseases deserve the adjective hereditary. They are "epilepsie, hemoptysie, pthysie, manie, melancholie, hysteria, hypochondria, \& apoplexie”. I believe that Pagès’ stern criteria, and strong solidism appealed to Vicq D’Azyr more than the other authors' "eclectic” positions, and that is why, although not given the prize by the Société Royale, it was this essay that Vic D’Azyr included in the Dictionnaire de Médécine of the Encyclopèdie Méthodique.

Pujol and Amoreux also used "homochrony” to separate humoral hereditary influences from non-hereditary ones. For them the transmission of the influence would occur through the semen (or the mother's blood) and it would then either affect the constitution during the first formation or remain in the body without effect until at a later,

\footnotetext{
33 Pagès (1798) p.162.

${ }^{34}$ Pagès (1798) p.160. This author explains homochrony based on a peculiar physiological theory. He sustains that each organ of the body has a certain period, in the individual's life, at which it exerts its main influence. It is when it is "switched on" when the period arrives that the organ weaknesses and latent predispositions are revealed, in the form of ailments or disease. See also p.163.
} 
determined stage, it would produce its evil effects. As Amoreux wrote, hereditary diseases are usually not carried by the children at birth but are "developed" at a certain age because it is transmitted "at the moment of formation, by an heterogenous mix in the prolific semen, the morbific principle enters, so to speak, into the germinal seed at the moment of the formation, and such principle with more or less strength is modified and altered during the growth of the foetus, of the child and the adult, and gives rise to a bad temperament, or to a disease, or finally to a simple disposition.”35 Homochrony was thus agreed as the clearest of “external” criteria for the presence of hereditary transmission by both solidists and humoralists.

But for some it was only one manifestation of the main characteristic that hereditary causes had been seen to possess: latency, or the ability to hide for some time in a healthy body without any sign or symptom. Atavism, of course, was the other important manifestation of this property linked to hereditary transmission. In their attempt to establish the category of “maladies vraiement héréditaires” most competitors for the Société Royale’s prize realized they needed to give some attention to the special status of hereditary causation. Louis and other sceptics had discarded as absurd any indirect or mute causation. Specially difficult to conceive was a morbific presence (be it constitutional or humoral) that could remain hidden for an entire lifetime (or several), get transmitted, and only manifest itself capriciously in a future generation. The transmission of predispositions not of actual diseases was the answer.

The idea of the existence of latent causes was thus in need of a credible physiological description that gave it some substance in order to transcend the hypothetical status. Several concurrents to the prizes seemed confident that through a distinction between kinds of

\footnotetext{
${ }^{35}$ Amoreux (1790) pp.17-18.
} 
causes the problem could be solved. The famous Fernel had provided the basic aristotelian frame: that a hereditary (predisposing) cause needed to be supplemented by a triggering, efficient cause, whose absence would leave the former one mute. What most competitors tried then to do was to flesh up this scheme based on their physiological biases. Materialist approaches to causation were favoured by most of them, both humoralists and solidists. Amoreux for instance, stressed that an important thing about both humoral and solidist causes is that they avoid all plastic, immaterial efficient forces, archées, etc., which he considers “empty” notions:“cette substitution des mots — he wrote— n’a jamais donné une idée plus claire de la chose”. ${ }^{36}$ Under a humoral account, latency is best explained by the permanence in the body of the tainted fluid for an indefinite time without acting noxiously in any of its parts (this gives a sort of predisposition). It is only when at some stage of the development of the solid parts, that one (or several) of them becomes vulnerable to the ill action and that the disease develops. Other triggering causes can be external ones (emotional, physical, climatic, or other) ${ }^{37}$. The solidist explanation of latency is based on the acquistion at the moment of the first formation of a physical flaw, or conformational mark that gives the predisposition to a given malfunction. It is only when a triggering cause (developmental or external) concurs that the disease is developed.

In any case, secondary, triggering causes were given a quite important role in the manifestation of the hereditary. This opens a clear avenue of intervention for hygienist preccupations of the period. These causes had however did not have a decisive role, as the variability of reaction within groups and families proved. "Everything being equal -wrote Amoreux- scondary causes will act in the same way over individuals similarly disposed,

\footnotetext{
${ }^{36}$ Amoreux (1790) p.13.

${ }^{37}$ Amoreux (1790) p.11.
} 
and will act differently over individuals differently disposed, which explains why within a family not all the children are always afflicted by their parents diseases”38 Authors could shed doubts over the possibility that either morbid humors or constitutional defects could really remain hidden in a healthy individual for long periods of time. The idea of a predisposition itself, and its being hereditarily transmitted, could also be attacked from a high, a prioristic ground. But to most 18th century French medical men these ideas provided an excellent resource for picturing the most irregular and untamable of their empirical set of observations.

In this case too, the analogy with the normal helped reinforce their belief. Homochronic phenomena (like dentition and puberty) on the one hand, and latent hereditary transmissions (like family male boldness received from the mother) on the other, could respond to an analogous kind of latent causation as the one they were advocating. Amoreux addressed another important problem for hereditary transmission, the striking variation among children of the same family, which was traditionally ascribed to to wildely varying influences at the time of conception. This author argues that the weight each kind of causal influence has in shaping the individual's temperament is not equal. Primary, humoral and solid, hereditary causes by far outweight the secondary, environmental ones. It seems undeniable to him, as to many others, that peculiarities of temperament and constitution run in families. As Pujol wrote

If it is true that the color of the skin is hereditary among humans, why wouldn't the temperament be so, the color ordinarily being both the sign and the effect if it? ... one cannot imagine how such a skillful man (Louis) could decide to deny such noticeable

\footnotetext{
${ }^{38}$ Amoreux (1790) p.12.
} 
and general fact... propagation of temperaments, through heritage and succesion is one of those general facts whose reality is easy to certify; one has only to examine with curiosity and detail different families among those gathered in the big cities. ${ }^{39}$

This general (holistic) fact however did not affect only the superficial qualities of colour, height, weight, and form of the body, extended its influence to the internal constitution of tissues and organs. Alongside clinical observations, hinted at by Pujol by the phrase "big cities”, it was surgery that provided, in the late 18th century, an new observational window that few of the contenders failed to mention. Resemblance within families could be traced to the minor details of inner configuration, opening a window to a multitude of other facts that increased both the number and the evidential strength of hereditary claims, especially when peculiar hidden defects began to turn up in autopsies. As Amoreux wrote

Anatomists, when exploring dead bodies of several individuals of some families have sometimes noticed a given conformity of structure or of defective organisation between them; and the examaples would undoubtedly be more frequent if they would follow more carefully this kind of research ${ }^{40}$

\footnotetext{
${ }^{39}$ Pujol (1802) p.248.

${ }^{40}$ Amoreux (1790) p.15. This confronts Albrecht von Haller's (1708-1777) denial of internal resemblance in Haller's critique of Buffon; Haller (1752)
} 
The general fact of widespread resemblance within families is thus used analogically to justify the belief in "pathological” resemblance. The importance of this analogical argument cannot be exaggerated fo the history of hereditarianism. As Georges Canguilhem has shown, the move from normality to pathology was not a natural one until well into the 19th century, so it was I believe an anomaly of the hereditary. ${ }^{41}$ Johann Friedrich Blumenbach (1752-1840) for instance reacted strongly against this kind of argument before adopting them himself, and popularised them ${ }^{42}$. Solidism —and surgery — tightened this analogical move amongst physicians. The emphasis on personal observation (and less reliance on ancient reports) and the attention to structural detail reinforced their confidence in the reality of hereditary transmission of individual (idiosynchratic) constitutional characters in general, and of the predispositions to diseases they could entail. Whatever the way the first "rudiment" or embryo came to be formed, they were convinced, there had to be a causal mechanism responsible for the impression on it of (some of) both of its parents particular constitutional characters. For the want of a better model (which generation theories did not provide) Pujol described this by a metaphor: "The same hand that traces so scrupulously the childs physionomie from those of the father and the mother has to move on to internal resemblances, and deliver with the same exactitude, organ after organ, entrail after entrail." 43

This hand, this mechanism whose basic external manifestations these late 18th century medical men were trying define, was to become, some decades afterward, the physiological mechanism of l'Hérédité. The notion of a general and unified explanation for hereditary transmission of both normal and pathological features was facilitated then by the

\footnotetext{
${ }^{41}$ Canguilhem (1972).

${ }^{42}$ Blumenbach (1795). For a discussion see López-Beltrán (1994).

${ }^{43}$ Pujol (1802) p.244.
} 
strenghtening of solidism. Humoral morbific causes would always maintain a connotation of a poison: alien, external disruptive influences (somehow more easily eradicated). On the other hand, the solid-solid communication (through a "normal” mechanism) of conformational flaws, provided with a perfect frame for the analogical reasoning described above. A frame that somehow could encompass naturally all the biological phenomena that came under the aegis of the adjective "hereditary”, normal or deviant. From family resemblance to hybridization; from transmission of physical deformity to hereditary disease. This strenghtening of the analogical domain, by unifying it under one kind of causal mechanism of transmission (and not a diversity) opened the door to a further step: from visible resemblances to invisible ones. Later, in the nineteenth century, this was to prove crucial for the leap from physical inheritance to moral inheritance.

Les Maladies Vraiment Héréditaires, as the French Société Royale de Médécine declared in 1791, a few months before its dissolution, was a category still in search of a precise definition. The stinging effect of Antoine Louis' arguments, together with the perceived stalemate in generation studies, had made it evident to the best prepared members of the French medical community, that if they were to preserve their authority with regard to hereditary transmission of all those mysterious diseases that seemed somehow to burst out spontaneously in some individuals within some families, they had to give ever more clear-cut characterizations of their main features, of their etiology and development. Chronic, constitutional diseases that once declared seemed impossible to eradicate, like gout, epilepsie, apoplexy, mania, or tuberculosis, were very difficult to account for except by a deep routed predisposition in the body. The category of a hereditary disease was one 
needed by the medical community, in part to account for its failure to prevent or cure these set of maladies, ${ }^{44}$ in part to gain and maintain authority over matters of public medicine. The discussion then had to be focused not so much on the reality of hereditary transmission but on the conformation of the theoretical space that was to describe them. To include more phenomena than those truly necessary, in other words, to have a category of hereditary disease so loosely defined as to have room for all diseases with some familiar pattern was absurd. Restrictive conditions based on the communication mechanism or route were needed, but the restrictions themselves had to be checked so that the category would not become impossible, as Louis had tried to argue it was. Pujol and Amoreux, the more enthusiastic defenders of wide range inclusion, saw the creation of some kind of gradient, or set of subclassifications based on kinds of causes and intensity of their effects, as the solution to the riddle. Amoreux proposed for instance four orders of truly hereditary diseases the first two are basically humoral, while the second two are solidist in cause: 1) those that are transmitted specifically, without a change of nature; 2) those (inespecific) that have an hereditary origin but change their nature; 3) essential bodily dispositions; and 4) bodily deformities that are transmitted and are indelible. As false hereditary diseases he considered all those products of accidental occurrences during pregnancy, non transmissible bodily defects, like taches, and all those opportunistic diseases that emerge from a weak constitution but that are not determined in any way. ${ }^{45}$ This left still too much room for the stern Société Royale judges, and only the solidist prudence of Rougemont and Pagès seems to have satisfied them here. Their strong

\footnotetext{
${ }^{44}$ As Ackerknecht has rather sternly put it: "heredity has always been the facile way of explaining the inexplicable”, Ackerknecht (1965) p.63. Waller extended this argument in his (2002). For an excellent recent exposition of the role of predisposing causes in the medical debates of early 19th century see Hamlin (1992).

${ }^{45}$ See Amoreux (1790) p.27.
} 
restriction of the category of the hereditary diseases, only the most obviously constitutional and chronic ones, leaves however a residual problem of how to account for the widespread occurrence of familial patterns that are not easily accountable by external contagions. The discussion around transmission through nourishment pre- and post-partum (through mother's blood and the nurse's milk) falls into this unstable domain. Again, the lack of a clear physiological description precludes the closure of the debate. The assault on the hereditary by those wishing to account for all its target phenomena through external causation was still an open possibility, but the set of distinctions (congenitalconnate) external observational criteria (homochrony) and causal analysis (latency) that most French physicians had agreed upon by the end of the 18th century seems to have given them a strong enough base for belief in a kind of independently describable system of transmission of physical peculiarities from parents to offspring that, in its de-pathologized way, could be synthetically referred to as Heredity.

\section{EPILOGUE}

In this paper I have tried to show that in European medical developments between the early $17^{\text {th }}$ century and the early $19^{\text {th }}$ century around the notion of hereditary disease we can find the first elements of causal structure and empirical criteria that instigated the conceptualisation of heredity as a major biological cause. I have focused on the outstanding theoretical analysis of hereditary transmission of disease provided in the late $18^{\text {th }}$ century by some French physicians responding to the challenge set by the Parisian Société Royale 
de Médécine ${ }^{46}$. I showed how we can find surprising and quite revealing intimations of the theoretical labour that lay ahead. These early attempts reveal an awareness of European physicians that they were dealing with a peculiar kind of natural mechanism that was not restricted to the transmission of pathological features and dispositions.

As I have discussed extensively elsewhere, the clarifications that physicians were able to make in this period laid the ground for the posterior apparition of heredity as a "as the carrier of a structured set of meanings that outlined and unified an emerging biological concept” ${ }^{\text {"47 }}$. The metaphor of the crafty tracing hand used by Pujol in his 1790 prize essay clearly points towards this copying process. In he same period there is striking evidence of similar advanced analysis of hereditary transmission in Britain, attributed to John Hunter (1728-1793) by his disciples. They are to be found in a series of paragraphs of his Principles of Surgery ${ }^{48}$, published in 1835, based on the transcriptions by James F. Palmer of his lectures given in 1786. In that work it is maintained that there exists in nature an hereditary principle that “ ... may be divided into two kinds: the transmission of natural properties, and the transmission of diseased, or what I shall call acquired or accidental properties” ${ }^{49}$. It is an intriguing question what exactly was on Hunter's mind but the evidence I have seen points towards a solidist analysis of the kind French physicians had advanced. ${ }^{50}$ The opposition of solidist vs. humoralist physiological accounts of hereditary transmission can be seen in $18^{\text {th }}$ century Britain by focusing on Hunter and Erasmus

\footnotetext{
${ }^{46}$ John Hunter's views on hereditary disease and those of his followers in Britain could have provided us an alternative case study. His views contrast in an interesting way with the humoralist, proteic, approach to hereditary transmission found in Erasmus Darwin. See for the latter Philip Wilson's piece in this volume.

${ }^{47}$ López-Beltrán (2002)

${ }^{48}$ Hunter, 1835-1837 (1786), vol. 1 pp.353-359

${ }^{49}$ Hunter, 1835-1837 (1786), vol. 1, p.353-354

${ }^{50}$ I have made a brief analysis of their views in López-Beltrán (1992) chapter 3.
} 
Darwin. Philip Wilson in this volume provides a fine exposition of how E. Darwin conceptualised the hereditary. ${ }^{51}$

By 1817 Antoine Petit, whom I believe had access to the manuscripts from the competition, wrote a small treatise on hereditary disease (that was immediately incorporated by the editors of the Dictionnaire des Sciences Médicales for the entry on "Héréditaire"(maladie)) that can be take to summarize the great lucidity that solidist French authors had achieved. This piece remained the most influential analysis published on the subject until the 1840 's ${ }^{52}$. It was a clear and convincing attack on humoralist heredity. Echoes of Petit's precisely worded piece can be found in works written sixty or seventy years later. Petit summarizes what he considers to be the main achievements that medics had attained in the definition of the hereditary cause. Heredity, he asserts, has to be based upon particular states of the bodily constitution communicated to children by parents. These states give an "organic disposition" to re-produce a given effect, for instance a particular disease. He adds that they can be both localized states, or states of the whole economie, but he denies that some kind of general qualities of the constitution (like weakness) that establish in the body vague and indefinite tendencies (to disease) are to be seen as similarly hereditary. In heredity a specific, one to one connection must be shown to exist. Among other things Petit praises the ancient distinction between predisposant and efficient causes as the main analytic resource to deal with the hereditary. He summarizes, with more clarity than any previous author, the determinant features of heredity. Latency, homochrony, atavism, all can be accounted for with a proper causal analysis. He upholds

\footnotetext{
51

${ }^{52}$ For a analysis of the presence of hereditary transmission of disease in the Dictionnaire des Sciences Médicales see López-Beltrán (2004b).
} 
the importance of separating clearly congenital and connate influences, and accepts that only through the process of generation can real hereditary influence be transmitted.

Petit however joins previous authors in condemning attempts to solve the mystery of heredity by an even deeper and more unsolvable mystery of generation. According to Petit, hypothetical systems of generation only confuse the issue. It is far more likely he adds that the proper observation of the patterns and nature of hereditary disease will illuminate the theorizing in generation, than the other way round. Although he is sceptical about the feasibility of any success, Petit leaves it to other specialists to decide over the real (intimate) nature of the inherited dispositions. The good observer however can on occasions find visible, exterior characters that are linked to the disposition, before its effects are noticeable. Generally, however, this is not the case, and though their is an organic base to hereditary causes, they usually remain hidden (latent) until the time, in the life pattern, comes for their expression.

This basically summarizes the rationale behind the adoption by a new generation of French physicians after the 1820’s of the noun hérédité as the conceptual focus (the node) through which a whole set of wide medical issues; the articulation between the needs of a new kind of socialized, hygienic program, and a need or theoretical replacements for abandoned conceptual tools like temperament or constitution in their humoral version, made heredity an ideal explanatory, and political resource. Laure Cartron’s contribution to this volume builds on the recent proposals in the sense that in the post Revolutionary period heredity became an important disciplinary resource for the Medical profession. ${ }^{53}$ The growing importance this concept acquired in the natural and the social sciences during the

\footnotetext{
${ }^{53}$ See Dowbiggin (1991), Waller (2001), López-Beltrán (2004a)
} 
rest of the $19^{\text {th }}$ century loses much of its mysterious abruptness once the developments in the medical scene are taken into account.

I have detailed in a recent paper the follow up of this story ${ }^{54}$, in which I show how at some point in the early decades of the $19^{\text {th }}$ century, French medical men and physiologists adopted the noun "hérédité" as the carrier of a structured set of meanings that outlined and unified an emerging biological concept. The elements of this domain had previously been loosely connected by the metaphorical mirroring between physical resemblance among parents and offspring and the passing on of property and titles through the generations and found applications ranging from the medical to the zoological, from the agricultural to the ethnological. It was in those areas where during the first half of the nineteenth century in several European countries, our modern concept of biological heredity was first adopted. I have shown there that our modern concept of biological heredity was first clearly introduced in a theoretical and practical setting by the generation of French physicians that were the direct inheritors of the physicians that I have discussed here, and that were active between 1810 and 1830. From a traditional focus on hereditary transmission of disease, influential French medical men moved towards considering heredity a central concept for the conception of the human bodily frame, and its set of physical and moral dispositions. The notion of heredity as a natural force, with wide ranging capabilities of transmitting differentially both fundamental and accidental characters was generalized by that generation of physicians with the help of contemporary naturalists and physiologists. By 1830 the term hérédité was widespread, and it shared the explanatory and semantic qualities of traditional medical concepts like constitution and temperament.

\footnotetext{
${ }^{54}$ López-Beltrán (2004b).
} 


\section{REFERENCES}

Documents from the Archives de la Ancienne Société Royale de Médécine, at Biblioteque de l'Academie Nationale de Médecine, Paris:

Amoreux, Pierre-Joseph, 1788, “Des Maladies Héréditaires”, 75 p. In the classification of the Bibliotèque de l'Academie Nationale it is document (200-2-2). I will be giving such codes for the documents below.

Amoreux, Pierre-Joseph, 1790, “Des Maladies Héréditaires” (10; 120-3-1).

Bésuchet, “Sur le Maladies Héréditaires”, 59p. (E; 200-2-3)

Gellei, Michel-Raphaël, 1788, “Morbi haereditarii” (N; 200-2-6).

Girard, 1790, “Recherches philosophiques et medicales sur les maladies héréditaires”, 80p., (12; 119-33-A).

Ladevère, 1790, “Essai sur la question proposé ....s’il existent vraiment des Maladies Héréditaires”. (119-30-5).

Pujol Alexis, 1788,“Essai sur le Maladies Héréditaires” (H;200-2-9).

Pujol Alexis, 1790, “Memoire sur les maladies héréditaires”(9; 120-3-5).

Minutes d'examen de memoires sur maladies héréditaires, 1788-1790 (181-23-1,5)

\section{Bibliography}

Ackerknecht, E. H. 1967. Medicine at the Paris Hospital 1794-1848, Baltimore, The John Hopkins Press.

Adams, J. 1814. A Treatise on the Hereditary Properties of Diseases, London, Callow.

Adams, J. 1817: Memoir of Life and Doctrine of the Late John Hunter, London, Callow. 
Blumenbach, J. F., 1865. The Anthropological Treatises, Anthropological Society, trsl. by T. Bendysche of his Works on Human Varieties $(1775,1795)$ London.

Borie, J. 1981. Les Mythologies de l'Hérédité au XIXe siècle, Paris, Editions Galilee Burton, Robert, 1621. Anatomy of Melancholy, London

Cabanis, P. J. G, 1802 . Rapports du Physique et du moral de l'Homme, in Lehec, Claude y Jean Cazeneuve (1956): Oeuvres Philosophiques de Cabanis, 2 vols., Paris, Presses Universitaires de France

Canguilhem, G., 1972. Le normal et le pathologique, Paris, Presses Universitaires Françaises, "galien”.

Cartron, L., in this volume, "Degeneration and Alienism in early Nineteenth century France”.

D’Azyr, V., Mahon, Moreau de la Sarthe, Thillaye (eds.) 1787-1830. Dictionnaire de Médecine de l'Encyclopedie Méthodique, 13 vols. Paris, Panckouke.

Dezeimeris, Ollivier, Raige-Delorme(eds.), 1828-1839, Dictionnaire Historique de la Médecine Ancienne et Moderne, 4 vols., Paris, Bechet Jeune.

Dowbiggin, I. R., 1991. Inheriting Madness; Professionalization and Psychiatric Knowledge in 19th-Century France, University of California Press

Fowler O. S., 1848. Hereditary Descent, Nueva York, Barker.

Haller, A., 1752. Reflexions sur le système de la génération de M. de Buffon, Geneve, Barrilot et Fils

Hamlin, C., 1992. "Predisposing Causes and Public Health in Early Nineteenth Century Medical Thought” in Social History of Medicine, vol. 5, 1, 43-70.

Huet, M.H. 1993, Monstruous Imagination, London, Harvard University Press, 
Hunter, J. 1861: Essays and Observations on Natural History, (edición de R. Owen), 2 vols., London

Hunter, J., 1835-1837 (1786), Principles of Surgery, edited by James F. Palmer , London, Callow

López-Beltrán, C., 1992. Human Heredity 1750-1870, The Construction of a Domain, $\mathrm{PhD}$ thesis, London, King's College.

López-Beltrán, C., 1994. "Forging Heredity, from Metaphor to Cause: a Reification Story” in Studies in the History and Philosophy of Science, vol. 25, 3, 211-235.

López-Beltrán, C., 1995. “«Les maladies héréditaires» 18th-century disputes in France”, in Revue d'Histoire des Sciences, vol. xlvii, 3, 307-350.

López-Beltrán, C., 2002. "Natural Things and Non-natural Things. The boundaries of the Hereditary in the $18^{\text {th }}$ century", in A Cultural History of Heredity I: $17^{\text {th }}$ and $18^{\text {th }}$ centuries, Preprint series, 222, pp. 67-88. Max Planck Institute for the History of Science, Berlin.

López-Beltrán, C., 2004a, El Sesgo Hereditario, Ámbitos Históricos del concepto de Herencia Biológica, Estudios sobre la Ciencia, UNAM.

López-Beltrán, C., 2004b, "In the Cradle of Heredity; French physicians and L'Hérédité Naturelle in the early $19^{\text {th }}$ century”, in Journal of the History of Biology, vol 37. 39-72.

López-Beltrán, C., forthcoming. "Haereditarii morbi in Early Modern Europe”, Micrologus, Italy.

Louis, A., 1749. Dissertation envoyée á l'Academie des Sciences de Dijon, pour le prix de l'année 1748, sur la question ...Comment se fait la transmission des maladies héréditaires?, Paris, Delaguet 
Lugt, M., forthcoming, “Maladies Héréditaires dans la France Médievale”, Micrologus, Italy.

Lyonnet R., 1647. Brevis Dissertatione de Morbis haereditariis, Lion, 4o., 87p

Malinas, Y. 1985. Zola et les Hérédités Imaginaires, (Paris: Expansion Scientifique Française)

Mandressi , R., 2004. Félix Vicq D’Azyr, l'anatomie, l’Etat, la médécine, Université Paris-5, BIUM

Meara, Dermutius, 1619. Pathologia Haereditaria generalis, Dublin

Mercado, Louis (Ludovico Mercatus). 1620. De morbis haereditariis. In Opera omnia medica \& chirurgica. Frankfurt: Typis Hartmanni Palthenij.

Montaigne, M. 1978. Essais. (1582), Bordeaux, S. Millange.

Montaigne, Michel. 1999. Essays, translated by John Florio. Renascence editions, University of Oregon. http://darkwing.uoregon.edu/\%7Erbear/montaigne/index.htm (last access 24/08/05).

Morgentaler, Goldie, 1999. Dickens and Heredity; When like begets like, London, Macmillan.

Olby, R., 1994. “Constitutional and Hereditary Disorders” in W. F. Bynum y R. Porter (eds.), Companion Encyclopedia of the History of Medicine, London, Routledge.

Pagès, J.-F., “Héréditaires (maladies)” 1798, in Dictionnaire de Médecine, part of the Encyclopedie Methodique, vol. VII, an VI de la République, chez Agasse. pp. $160-176$

Petit, A., 1817. Essai sur les maladies héréditaires, Paris, Gabon 
Portal, A., 1808. “Considerations sur la nature et le traitement de quelques maladies héréditaires, ou de famille”, in Memoires de l' Institute Nationale de France, vol. 8, 2, p. 156.

Pujol de Castres, A., 1802. "Essai sur les Maladies Héréditaires” in Oeuvres Médicales, 4 vol., Castres, in 8o. 2a ed.

Renzi, S. de, in this volume, "Resemblance, paternity and imagination in early modern courts”

Rey G., 1749. Sur la transmission des Maladies Héréditaires, qui a balancé le Prix de l'Academie de Dijon en 1748. 12o. 24pp.

Roger, J. 1963. Les sciences de la vie dans la pensée française du xviiie siècle, Paris, Armand Colin.

Roger, J.1964: “Jean Fernel et les problèmes de la médecine de la Renaissance”, in Les conferences du Palais de la Découverte, D, 70, Paris

Rougemont J.-C., 1794. Abhandlung über die erblichen krankheiten;, (Translator: Friedrich Gerhard Wegeler), Frankfurt.

Sociéte Royale de Médécine, 1786-1788: Histoire et Mémoires de la Societé Royale de Médecine, vols. IX y X, Paris.

Steinau, J. H., 1843. Pathological \& Philosophical Essay on Hereditary Diseases, London, Marshall \& Co.

Waller, J.C., 2001. "Ideas of Heredity, Reproduction and Eugenics in Britain, 1800-1875” Studies in History and Philosophy of Biology and Biomedical Sciences, 32, 457-489

Waller, J.C., 2002. ““'The Illusion of an Explanation”; The Concept of Hereditary Disease, 1770-1870”, Journal of the History of Medicine and Allied Sciences, 57: 410-448 
Williams, E. A., 1994. The Physical and the Moral: Anthropology, Physiology, and Philosophical Medicine in France, 1750-1850, Cambridge, Cambridge University Press.

Wilson, P.K., in this volume, "Erasmus Darwin and the "Noble” Disease (gout): conceptualizing Heredity and Disease in Enlightenment England”

Zirckle, C., 1946. “The Early History of the Idea of the Inheritance of Acquired Characters and of Pangenesis”, in Transactions of the American Philosophical Society, 38, 91-151. 